\title{
Genetics of variation in adiponectin in pedigreed baboons: evidence for pleiotropic effects on adipocyte volume and serum adiponectin
}

\author{
ME Tejero ${ }^{1}$, VS Voruganti ${ }^{1}$, IP Rodríguez-Sánchez ${ }^{2}$, JM Proffitt ${ }^{1}$, J Blangero ${ }^{1}$, LA Cox ${ }^{1,3}$, MC Mahaney ${ }^{1,3}$, \\ J Rogers ${ }^{1,3}$, JL VandeBerg ${ }^{1,3}$, SA Cole ${ }^{1}$ and AG Comuzzie ${ }^{1,3}$ \\ ${ }^{1}$ Department of Genetics at Southwest Foundation for Biomedical Research, San Antonio, TX, USA; ${ }^{2}$ Departamento de Bioquimica, \\ Facultad de Medicina, Universidad Autónoma de Nuevo León, Nuevo León, México and ${ }^{3}$ Southwest National Primate Research Center, \\ San Antonio, TX, USA
}

To detect and localize the effects of genes influencing variation in adiponectin mRNA and protein levels, we conducted statistical genetic analyses of circulating concentrations of adiponectin and adiponectin (ADIPOQ) mRNA expression in omental adipose tissue in adult, pedigreed baboons (Papio anubis). An omental adipose tissue biopsy and blood sample were collected from 427 baboons from the colony at the Southwest Foundation for Biomedical Research, San Antonio, TX. Total RNA was isolated from adipose tissue and adiponectin mRNA levels were assayed by real-time, quantitative reverse transcriptase-PCR. Adiponectin, insulin, glucose, cholesterol, high-density lipoproteins and triglycerides were measured in fasting serum. Quantitative genetic analyses were conducted for adiponectin mRNA and serum protein using a maximum likelihood-based variance decomposition approach. A genome-wide linkage analysis was conducted using adiponectin mRNA and protein levels as phenotypes. Significant heritability was estimated for ADIPOQ mRNA levels $\left(h^{2}=0.19 \pm 0.07\right.$, $P=0.01)$ and protein levels $\left(h^{2}=0.28 \pm 0.14, P=0.003\right)$. Genetic correlations were found between adiponectin protein and body weight $\left(\rho_{\mathrm{G}}=-0.51, P=0.03\right)$, cell volume $\left(\rho_{\mathrm{G}}=-0.73, \quad P=0.04\right)$, serum triglycerides $\left(\rho_{\mathrm{G}}=-0.67\right.$, $P=0.03$ ), and between adiponectin mRNA and glucose $\left(\rho_{\mathrm{G}}=0.93, P<0.01\right)$. A logarithm of odds score of 2.9 was found for ADIPOQ mRNA levels on baboon chromosome 4p, which is orthologous to human $6 p 21$. There is a significant genetic component affecting variation in the analyzed traits, and common genes may be influencing adiponectin expression, adipocyte volume, body weight and circulating triglycerides. The region on $6 \mathrm{p} 21$ has been linked to diabetes-related phenotypes in human studies.

Heredity (2008) 100, 382-389; doi:10.1038/sj.hdy.6801089; published online 20 February 2008

Keywords: adiponectin; animal model; adipose tissue; QTL; pleiotropy; baboon

\section{Introduction}

The hormone adiponectin is produced by white and brown adipose tissue in humans (Kershaw and Flier, 2004), rodents (Lihn et al., 2004) and nonhuman primates (Hotta et al., 2001). The adiponectin mRNA transcript (ADIPOQ) is the most abundant in adipose tissue, and the translated product is present in plasma in high concentrations ( $1 \%$ of protein in human plasma) (Maeda et al., 1996; Kershaw and Flier, 2004). Adiponectin has been consistently associated with regulation of insulin sensitivity, lipid metabolism, inflammation and the risk for the development of atherosclerosis (Fruebis et al., 2001; Matsuda et al., 2002; Shimada et al., 2004). Circulating adiponectin levels are low in obesity and inflammation (Bruun et al., 2003; Fernández Real et al., 2003), insulin resistance (Silha et al., 2003; Nakamura

Correspondence: Dr ME Tejero, Department of Genetics, Southwest Foundation for Biomedical Research, 7620 NW Loop 410, San Antonio, TX 78245, USA.

E-mail: ltejero@sfbrgenetics.org

Received 2 April 2007; revised 14 September 2007; accepted 8 November 2007; published online 20 February 2008 et al., 2004) and type 2 diabetes (Weyer et al., 2001 ), and higher concentrations of this protein are associated with improvement of metabolic abnormalities (Esposito et al., 2003).

Previous investigations have reported obesity and metabolic abnormalities in baboons, which resemble those observed in human obesity and the metabolic syndrome (Banks et al., 2003; Comuzzie et al., 2003) and have confirmed the value of this species as an animal model for the study of obesity-related conditions. An earlier study in our laboratory found that adiponectin levels in plasma are inversely correlated with insulin resistance in adult baboons (Tejero et al., 2004).

Circulating levels of adiponectin are heritable (Comuzzie et al., 2001; Lindsay et al., 2003; Butte et al., 2005; Pollin et al., 2005). Genome-wide scan analyses have identified quantitative trait loci (QTL) linked to variation in adiponectin levels in several geographically and ethnically diverse human populations. Significant linkage with logarithm of odds score (LOD score) $>3$ has been reported on chromosomes 5, 14 (Comuzzie et al., 2001) and 11 (Tejero et al., 2007) and signals on chromosomes $10 p$ and $3 p$ have been replicated across different populations (Comuzzie et al., 2001; Chuang 
et al., 2005; Tejero et al., 2007). The present investigation conducted a genome-wide scan using adiponectin mRNA expression levels and circulating protein levels in baboons as quantitative phenotypes and explored the pleiotropy between adiponectin phenotypes and traits associated with the metabolic syndrome.

\section{Methods}

\section{Animals}

The studied sample consisted of 427 adult baboons from the pedigreed colony at the Southwest National Primate Research Center located at the Southwest Foundation for Biomedical Research at San Antonio, TX, with 130 male and 297 nonpregnant, nonlactating females. All baboons are gang-housed and fed ad libitum on a standard low-fat chow diet (Harlan Tecklad 15\% Monkey Diet, 8715).

\section{Genotypes}

Baboon genomic DNA was isolated from leukocytes using a phenol-chloroform method and amplified using fluorescently labeled, published human PCR primers as described elsewhere (Cox et al., 2006). The genotyping procedure in the present study included 330 markers, consisting of short tandem repeat polymorphisms covering the autosomes and spaced at approximately 7.2-cM intervals. Genotypes were analyzed using gel electrophoresis on ABI automated sequencers and Genescan, Genotyper and Gene mapper software (Applied Biosystems, Foster City, CA, USA). Details of the latest baboon short tandem repeat polymorphism map have been previously published (Cox et al., 2006).

\section{Phenotypes}

All samples were collected after an overnight fast (12 h), with the animals under sedation with ketamine. An $8 \mathrm{ml}$ sample of blood was drawn from the antecubital vein and after clotting all samples were centrifuged for $10 \mathrm{~min}$ at $2000 \mathrm{~g}$ for serum separation. The serum was then decanted and frozen at $-80^{\circ} \mathrm{C}$ for subsequent analyses of glucose, lipids and proteins. A $1 \mathrm{~g}$ biopsy of omental adipose tissue was obtained from all baboons. Biopsies were analyzed immediately for cell volume as described by Lewis et al. (1986). The remaining sample was frozen for further extraction of total RNA using Trizol Reagent (Molecular Technology, Gaithersburg, MO, USA). The RNA yield and purity were analyzed by ultraviolet spectrophotometry. Integrity of RNA was determined by electrophoresis in a $1.2 \%$ denaturant agarose gel stained with ethidium bromide. All samples were treated with DNAse (Invitrogen, Carisbad, CA, USA) for $15 \mathrm{~min}$ at $37^{\circ} \mathrm{C}$ to eliminate traces of genomic DNA.

\section{Cloning of a baboon adiponectin cDNA fragment}

A cDNA fragment of baboon adiponectin was cloned from total RNA of omental adipose tissue by the twostep methods of reverse transcription followed by a polymerase chain reaction (RT-PCR) method using the THERMOSCRIPT RT-PCR System (Gibco BRL Life Technologies Inc., Gaithersburg, MD, USA). Reverse transcription was conducted with hexamers (Invitrogen). Two microliters of the cDNA product were used for the amplification of the adiponectin transcript. Published primers for the rhesus monkey sequence were used
(Hotta et al., 2001). The amplified product was cloned using the CloneAmp pAMP1 kit (Gibco BRL Life Technologies Inc.). The cloned baboon adiponectin cDNA fragment was sequenced using an ABI 3100 automated DNA sequencer with Big Dye Terminator kit (Applied Biosystems). The sequenced product was analyzed in BLAST (www.ncbi.nlm.nih.gov) for prediction of the encoded amino acids and alignment with similar sequences.

\section{Quantification of adiponectin mRNA}

Adiponectin mRNA expression in omental adipose tissue was measured by real-time, quantitative RT-PCR (Taq Man, Applied Biosystems). The primers and probe sequences were designed with the Primer Express Software Version 1 (Applied Biosystems) using the baboon adiponectin cDNA clone. The sequences of forward and reverse primers were $5^{\prime}$-TCCTCCTGCCT GTCCTGG-3' and 5'-CGCCCTCCTGAATCTTCTCAT-3', respectively. The sequence for the adiponectin probe was 5'-TAAACGTGGACCAGGCCTCCGG-3'. Ribosomal 18S RNA (rRNA) was used as an internal control and measured by the Universal $18 \mathrm{~S}$ system from Ambion (Austin, TX, USA). The primers to competimers ratio was 4:6. The probe for $18 \mathrm{~S}$ was the rRNA Ambiprobe from Applied Biosystems. A sample of $50 \mathrm{ng}$ of total RNA was used per assay. Data were obtained as $C_{t}$ values (the number of cycles at which logarithmic plots of PCR product accumulation cross a specific threshold line), according to the manufacturer's specifications (Applied Biosystems) and transformed into number of mRNA copies. Adiponectin expression was corrected for $18 \mathrm{~S}$ ribosomal mRNA by dividing by the number of copies.

Assays for glucose, insulin, adiponectin protein and lipids Glucose was analyzed with an Analox spectrophometer. Lipids were assayed by standard enzymatic procedures and insulin and adiponectin were assayed by quimioluminiscence (Linco Research, Lake Charles, MO, USA). Inter and intra-assay variation in all parameters was $<5 \%$. Comparison of adiponectin circulating concentrations between male and female baboons was conducted by Student's $t$-test for independent samples.

\section{Analysis of tissue-specific gene expression of baboon adiponectin}

Tissues from stomach fundus, ovary, skeletal muscle, omental and subcutaneous adipose tissue, monocytes, pancreas, hypothalamus, small intestine and colon were isolated from a euthanized adult baboon. Placenta was obtained from a full-term baboon pregnancy, after delivery. RNA was isolated from the tissues and the adiponectin transcript was amplified from the samples by two-step RT-PCR as described above. Reverse transcription was conducted as described above. Two microliters of the cDNA product were used for the amplification of the adiponectin transcript with published primers, and 18S ribosomal RNA expression was used as control. Samples were analyzed on a $2 \%$ agarose gel stained with ethidium bromide, and the presence of a PCR product of the correct size was considered evidence for tissue-specific adiponectin gene expression. 
Statistical genetic analysis

Statistical genetic analyses were conducted using the computer package SOLAR (Almasy and Blangero, 1998), which applies a maximum likelihood-based, variance decomposition method. For this analysis, the phenotypic variance $\left(\sigma_{\mathrm{P}}^{2}\right)$ was divided into two major components, the additive genetic $\left(\sigma_{\mathrm{G}}^{2}\right)$ and nongenetic $\left(\sigma_{\mathrm{E}}^{2}\right)$, or environmental. Heritability can be calculated as the proportion of the trait variance that results from the additive genetic effects $\left(h^{2}=\sigma_{\mathrm{G}}^{2} / \sigma_{\mathrm{P}}^{2}\right)$. The likelihood of the model is estimated and compared with the likelihood of a model in which the effect is absent (heritability of zero). The approximately asymptotic distribution is a $1 /$ $2: 1 / 2$ mixture of a $\chi^{2}$ variable with one degree of freedom and a point mass at zero. Heritabilities of the studied variables were estimated after accounting for the mean effects of covariates including sex, age, sex-by-age interaction, age ${ }^{2}$, sex by age ${ }^{2}$ and weight. Significance of the residual heritability estimates was assessed by likelihood ratio test. To investigate shared genetic effects (pleiotropy) between pairs of phenotypes, bivariate quantitative genetic analyses were performed. In these analyses, we obtained maximum likelihood estimates of both additive genetic and environmental correlations ( $\rho_{\mathrm{G}}$ and $\rho_{\mathrm{E}}$, respectively) between adiponectin protein and mRNA levels and the other studied phenotypes. From these estimates, we calculated phenotypic correlations $\left(\rho_{\mathrm{P}}\right)$ between trait pairs that accounted for the nonindependence between relatives as:

$$
\rho_{\mathrm{p}}=\rho_{\mathrm{G}} \sqrt{h_{1}^{2}} \sqrt{h_{2}^{2}}+\rho_{\mathrm{E}} \sqrt{\left(1-h_{1}^{2}\right)} \sqrt{\left(1-h_{2}^{2}\right)}
$$

Genome-wide, multipoint linkage scans were conducted in SOLAR using adiponectin mRNA and protein levels using body weight, sex, age and their interaction as covariates. Empirical LOD score adjustment was conducted by the method described by Blangero et al. (2000). To control for the overall false positive rate in whole genome linkage screens, we employed a modification of

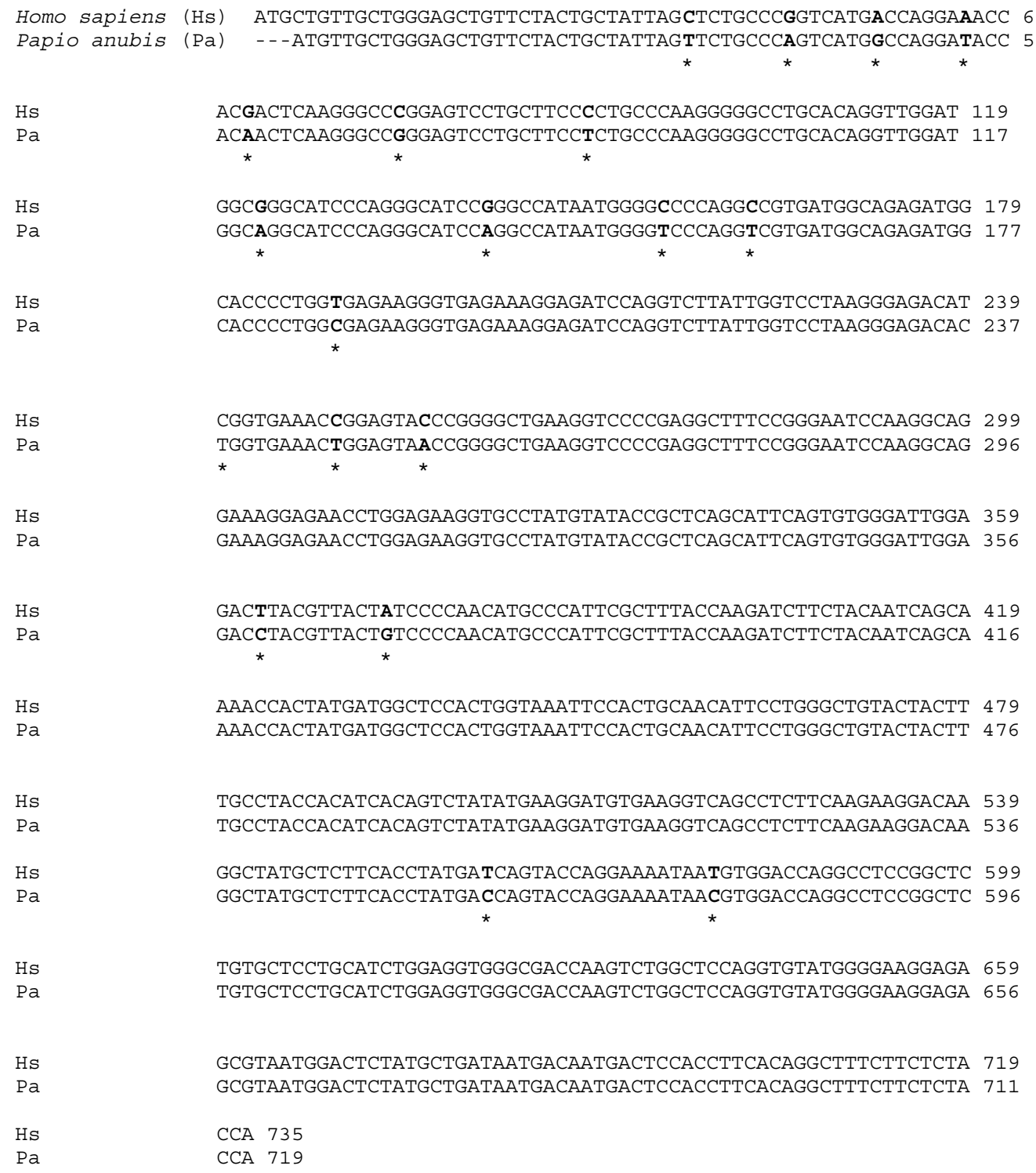

Figure 1 Comparison between baboon (Papio anubis) and human (Homo sapiens) adiponectin cDNA sequence. *Indicates difference in nucleotide sequence. 
$\mathrm{Hs}$

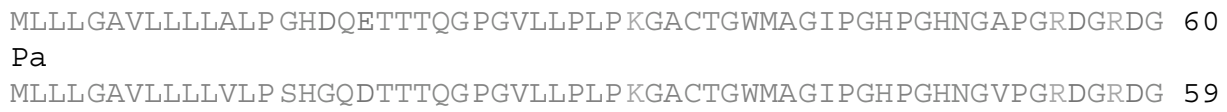

Figure 2 Adiponectin amino-acid sequences of Homo sapiens and Papio anubis. * Indicates difference in amino acid sequence.

Table 1 Characteristics of the studied baboons

\begin{tabular}{|c|c|c|c|c|}
\hline Trait & $\begin{array}{c}\text { Mean } \pm \text { s.d. } \\
\text { Male }(\mathrm{n}=130)\end{array}$ & $\begin{array}{c}\text { Mean } \pm \text { s.d. } \\
\text { Female }(\mathrm{n}=297)\end{array}$ & $\mathrm{h}^{2} \pm$ s.e. & $\mathrm{P}$ \\
\hline Age (years) & $12.1 \pm 3.9$ & $15.9 \pm 4.9$ & & \\
\hline Weight (kg) & $31.5 \pm 4.5$ & $19.5 \pm 4.0$ & $0.79 \pm 0.10$ & 0.001 \\
\hline Glucose (mg per $100 \mathrm{ml})$ & $79.5 \pm 1.16$ & $82.4 \pm 1.2$ & $0.27 \pm 0.10$ & 0.0002 \\
\hline Insulin $(\mu \mathrm{IU}$ per $100 \mathrm{ml})$ & $23.4 \pm 0.02$ & $42.6 \pm 0.06$ & $0.12 \pm 0.09$ & 0.057 \\
\hline Cholesterol $(\mathrm{mg}$ per $100 \mathrm{ml})$ & $92.9 \pm 23.5$ & $121.8 \pm 33.8$ & $0.67 \pm 0.10$ & $1.4 \times 10^{-19}$ \\
\hline HDL-C (mg per $100 \mathrm{ml})$ & $50.6 \pm 11.9$ & $53.9 \pm 13.3$ & $0.78 \pm 0.11$ & $6.8 \times 10^{-19}$ \\
\hline Triglycerides (mg per $100 \mathrm{ml}$ ) & $44.6 \pm 1.4$ & $62.5 \pm 1.4$ & $0.32 \pm 0.11$ & 0.0005 \\
\hline Adiponectin mRNA/18S & $21.2 \pm 2.3$ & $20.7 \pm 2.5$ & $0.19 \pm 0.07$ & 0.01 \\
\hline Adiponectin $\left(\mu \mathrm{g} \mathrm{ml}^{-1}\right)$ & $10.3 \pm 0.14$ & $11.8 \pm 0.12$ & $0.28 \pm 0.14$ & 0.003 \\
\hline Cell volume (nl) & $0.39 \pm 0.4$ & $0.58 \pm 0.42$ & $0.20 \pm 0.12$ & 0.02 \\
\hline
\end{tabular}

Abbreviation: HDL-C, high-density lipoprotein cholesterol.

Table 2 Relative pairs

\begin{tabular}{rrl}
\hline & 427 & Self \\
121 & Parent-offspring \\
255 & Siblings \\
2 & Grandparent-grandchild \\
43 & Avuncular \\
& 2842 & Half siblings \\
& 566 & Half avuncular \\
& 3 & First cousins \\
& 19 & Half first cousins \\
& 1 & Half sibling and first cousin \\
& 51 & Half siblings and first cousins \\
& 7 & Half sibling and half avuncular \\
Total & 4337 & \\
\hline
\end{tabular}

an approach advanced by Feingold et al. (1993) that takes into account the finite marker density in the linkage map utilized and (as an indicator of pedigree complexity and size) the estimated mean recombination rate in the baboon pedigrees. In the current data set, the thresholds for significant (at $\alpha=0.05$ ) and suggestive linkage on a genome-wide basis are $\mathrm{LOD}=2.75$ and $\mathrm{LOD}=1.53$, respectively.

Variables were approximately normalized by $\log$ transformation before analyses. The selection of the positional candidate genes was conducted using the NCBI database.

\section{Results}

The baboon adiponectin cDNA sequence spans $695 \mathrm{bp}$ and is $97 \%$ identical to human and $100 \%$ identical to the rhesus monkey sequence. There are differences in 7 of the 240 predicted amino acids between human and baboon adiponectin (Figures 1 and 2). The adiponectin transcript was found in omental and subcutaneous adipose tissue. No other tissue had detectable levels of expression of this gene (Figure 4).

The profile of the studied animals is shown in Table 1. Adiponectin levels in serum were significantly higher in female baboons $(P<0.05)$ but no difference by sex was found in levels of adiponectin mRNA expression. 
The distribution of the relative pairs in the present study is shown in Table 2. The univariate analysis estimated a significant heritability of $128 \%$ for levels of circulating adiponectin protein and 19\% for adiponectin mRNA levels in omental adipose tissue using sex, age, age $^{2}$ and their interactions as covariates. As observed in Table 1, all the analyzed traits were significantly heritable.

The genetic and environmental correlations between adiponectin protein and mRNA levels and the other analyzed variables are shown in Tables 3 and 4 . Significant phenotypic correlations were observed between adiponectin protein and body weight and cell volume. Genetic correlations were significant between adiponectin protein and triglyceride levels, cell volume and body weight. Adiponectin mRNA had significant phenotypic correlations with body weight and significant genetic correlations with glucose levels.

Genome-wide scans were conducted using adiponectin mRNA abundance and protein as quantitative traits. As observed in Figures $3 a$ and $b$, an LOD score of 2.9 (genome-wide $P=0.033$ ) was found on baboon chromosome $4 \mathrm{p}$, which is orthologous to human $6 \mathrm{p} 21$, for adiponectin mRNA levels from omental adipose tissue (Figure 4). Figures $3 \mathrm{a}$ and $\mathrm{b}$ show string plots organized by human orthologous regions. Figure 3c shows the lack of overlap on chromosome 6 p21 between the signals for adiponectin protein and mRNA levels. The highest evidence for a QTL influencing circulating levels of adiponectin protein in this investigation was found on human chromosome 4 (LOD score $=1.1$ ).

\section{Discussion}

Adiponectin sequence is highly similar to human at the cDNA and amino-acid level. As expected, adiponectin mRNA expression was found in omental and subcutaneous adipose tissue; however, no expression was observed in baboon placenta. Expression and release of adiponectin protein from human placenta has been reported and it is believed to play a role in insulin resistance during pregnancy (Chen et al., 2006). The lack of expression of adiponectin in the baboon placenta remains to be explored.

The circulating levels of adiponectin in baboon are similar to those reported for human with females having higher levels of this protein. Heritability of adiponectin protein in serum and the other analyzed traits resemble values in previous human studies and in baboons (Cai et al., 2004), indicating a significant genetic contribution to the variance of each of these traits.

The bivariate analyses revealed significant genetic correlations, suggesting the presence of pleiotropy between some of the analyzed phenotype pairs. A highly significant genetic correlation was found between adiponectin mRNA in omental adipose tissue and circulating protein levels indicating that $60.8 \%$ of the additive genetic variation in these two phenotypes, as expected, is attributable to the effects of the same gene or genes.

Negative phenotypic correlations between adiponectin protein and cell volume, and body weight indicate the inverse covariation between these phenotypes. This is the first study, to our knowledge, of pleiotropy between adipose cell volume and adiponectin expression levels. The present results indicate the presence of a significant genetic component and suggest the exertion of pleiotropic effects on adiponectin protein, cell volume, body weight and triglycerides.

Adiponectin mRNA levels and fasting glucose levels have shared genetic effects. According to these results, common genes are influencing these phenotypes in an inverse manner. These observations are concordant with findings in previous human and rodent studies showing

Table 3 Phenotypic $\left(\rho_{\mathrm{P}}\right)$, genetic $\left(\rho_{\mathrm{G}}\right)$ and environmental $\left(\rho_{\mathrm{E}}\right)$ correlations \pm s.e. between adiponectin protein and the analyzed variables

\begin{tabular}{lrrrrr}
\hline Trait & $\rho_{P}$ & $\mathrm{P}$ & $\rho_{G}$ & $\mathrm{P}$ & $\rho_{E}$ \\
\hline Glucose & 0.22 & 0.92 & $0.31 \pm 0.12$ & 0.12 & $0.19 \pm 0.12$ \\
Insulin & -0.15 & 0.06 & $-0.09 \pm 0.67$ & 0.87 & $-0.17 \pm 0.12$ \\
Cholesterol & 0.02 & 0.26 & $-0.16 \pm 0.24$ & 0.49 & $0.31 \pm 0.16$ \\
Triglycerides & -0.17 & 0.39 & $-\mathbf{0 . 6 7} \pm 0.29$ & $\mathbf{0 . 0 3}$ & 0.12 \\
HDL & 0.06 & 0.24 & $0.03 \pm 0.26$ & 0.90 & 0.05 \\
Cell volume & $-\mathbf{0 . 2 4}$ & $\mathbf{0 . 0 0 0 0 3}$ & $-\mathbf{0 . 7 3} \pm 0.34$ & $\mathbf{0 . 0 4}$ & $0.20 \pm 0.20$ \\
Adiponectin mRNA & -0.07 & 0.32 & $\mathbf{0 . 7 8} \pm 0.27$ & $-0.08 \pm 0.13$ & 0.15 \\
Body weight & $-\mathbf{0 . 2 2}$ & $\mathbf{0 . 0 0 4}$ & $-\mathbf{0 . 5 1} \pm 0.37$ & $\mathbf{0 . 0 3}$ & $0.11 \pm 0.11$ \\
\end{tabular}

Abbreviation: HDL, high-density lipoproteins.

Statistically significant values are in bold.

Table 4 Phenotypic $\left(\rho_{\mathrm{P}}\right)$, genetic $\left(\rho_{\mathrm{G}}\right)$ and environmental $\left(\rho_{\mathrm{E}}\right)$ correlations \pm s.e. between adiponectin mRNA in omental adipose tissue and the analyzed variables

\begin{tabular}{|c|c|c|c|c|c|c|}
\hline Trait & $\rho_{P}$ & $\mathrm{P}$ & $\rho_{G}$ & $\mathrm{P}$ & $\rho_{E}$ & $\mathrm{P}$ \\
\hline Glucose & 0.01 & 0.65 & $-\mathbf{0 . 5 0} \pm 0.40$ & 0.04 & $0.15 \pm 0.09$ & 0.12 \\
\hline Insulin & 0.01 & 0.62 & $-0.16 \pm 0.70$ & 0.82 & $0.04 \pm 0.09$ & 0.62 \\
\hline Cholesterol & 0.09 & 0.10 & $0.19 \pm 0.27$ & 0.46 & $0.04 \pm 0.72$ & 0.72 \\
\hline Triglycerides & 0.07 & 0.60 & $0.06 \pm 0.36$ & 0.88 & $-0.07 \pm 0.11$ & 0.55 \\
\hline HDL & 0.09 & 0.09 & $0.16 \pm 0.26$ & 0.53 & $0.07 \pm 0.15$ & 0.65 \\
\hline Cell volume & -0.16 & 0.43 & $-0.90 \pm 0.65$ & 0.80 & $0.01 \pm 0.09$ & 0.70 \\
\hline Body weight & -0.14 & 0.02 & $-0.38 \pm 0.15$ & 0.14 & $0.05 \pm 0.12$ & 0.86 \\
\hline
\end{tabular}

Abbreviation: HDL, high-density lipoproteins.

Statistically significant values are in bold. 

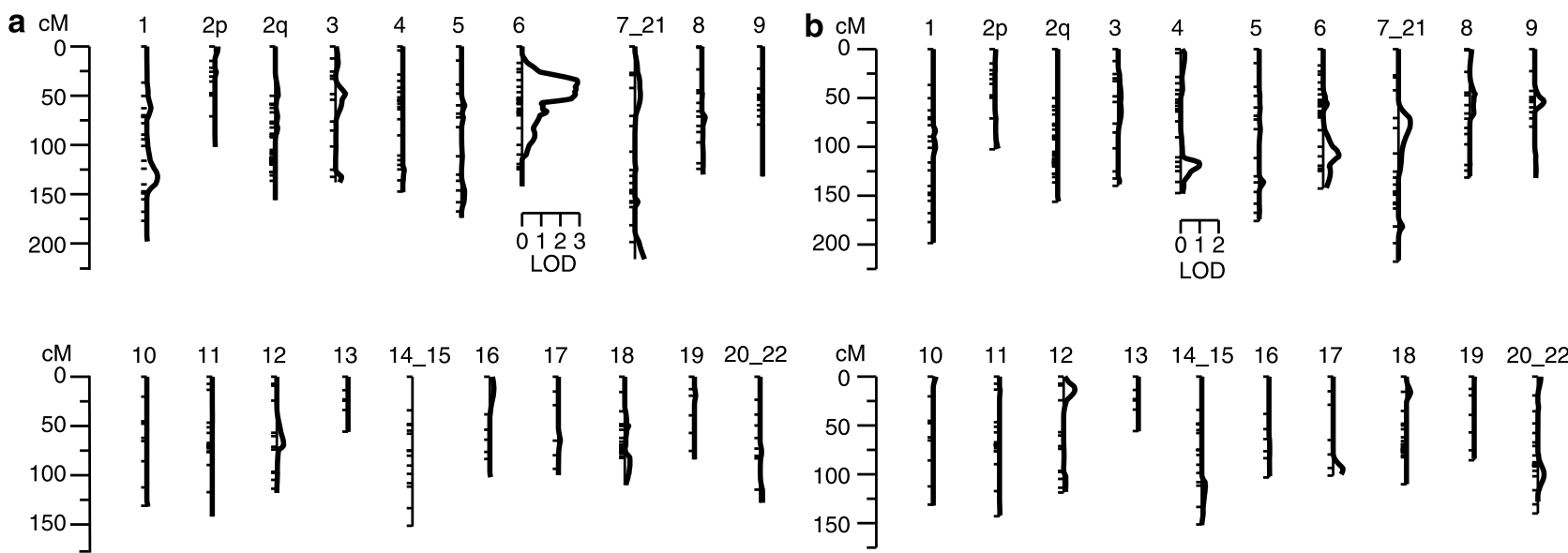

C Chromosome 6

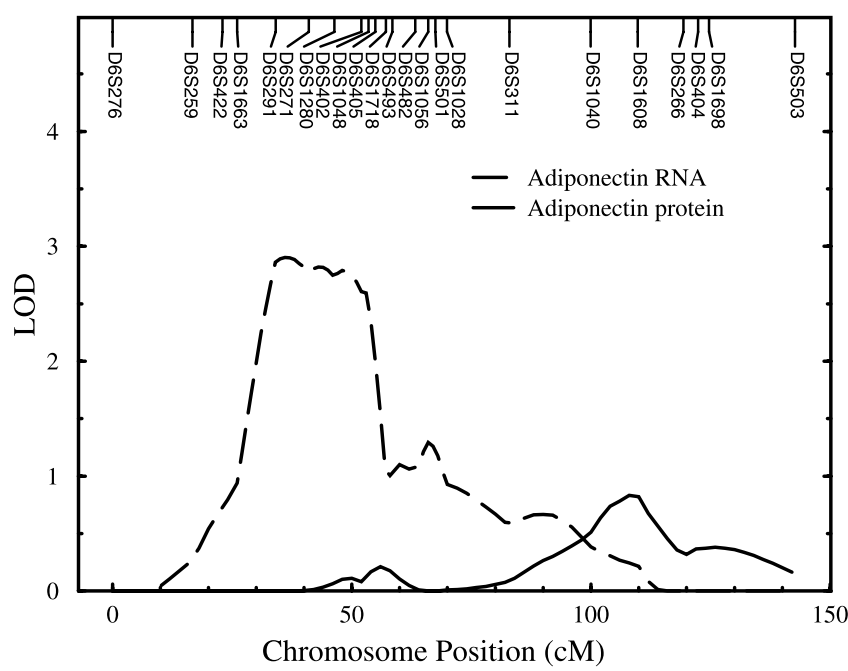

Figure 3 (a) Adiponectin mRNA genome-wide scan. Numbers show human orthologous regions. (b) Adiponectin circulating protein genome-wide scan. Numbers show human orthologous regions. (c) Signals on chromosome 6p21 for adiponectin mRNA and protein levels.

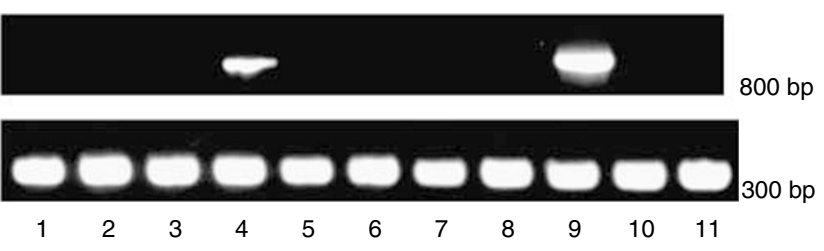

Figure 4 Expression of adiponectin mRNA across tissues in baboons. Tissue-specific expression of baboon adiponectin mRNA (upper panel) and 18S ribosomal subfraction (lower panel). (1) Stomach fundus, (2) ovary, (3) colon, (4) subcutaneous adipose tissue, (5) small intestine, (6) hypothalamus, (7) placenta, (8) monocytes, (9) omental adipose tissue, (10) pancreas and (11) liver. Agarose gel (2\%) stained with ethidium bromide was used. A volume of $5 \mu \mathrm{l}$ of PCR reaction was loaded per well.

an inverse association between adiponectin levels, glucose tolerance, adiposity and lipid metabolism (Fruebis et al., 2001; Hotta et al., 2001; Esposito et al., 2003; Kershaw and Flier, 2004; Shimada et al., 2004). The present investigation provides information on the genetic component present within these associations.
The $\rho_{\mathrm{G}}$ value of the genetic correlation of adiponectin mRNA and adipocyte volume is not statistically significant; however, the direction and magnitude of the estimated genetic correlation support the correlation observed with adiponectin protein levels. These data indicate the possible exertion of pleiotropic effects on adiponectin expression and adipose cell volume. The increase in adipocyte volume has been related to upregulation of the expression of pro-inflammatory cytokines (Garaulet et al., 2000; Weyer et al., 2000; Heilbronn et al., 2004; Rotter Sopasakis et al., 2004; Pausova, 2006), insulin resistance and the risk for type 2 diabetes (Weyer et al., 2000). It has been proposed that this relationship could be mediated by changes in intracellular signaling affecting regulation of gene expression (Weyer et al., 2000; Pausova, 2006). Enlargement of adipocytes may be caused by less proliferation and differentiation of these cells and may be accompanied by deposit of fat in nonadipose tissues (Heilbronn et al., 2004). A negative genetic correlation between adiponectin protein and triglycerides has been observed in human family studies in Hispanic children 
$\left(\rho_{\mathrm{G}}=-0.24, P<0.05\right)$ (Butte et al., 2005) and adults $\left(\rho_{\mathrm{G}}=-0.35, P<0.05\right)$ (Comuzzie et al., 2007), indicating the presence of pleiotropy. The genetic correlations in baboons were higher than those reported in studies of human families and we considered that the homogeneity in diet and environmental factors may contribute to the larger pleiotropic genetic effects in this species.

While no significant evidence of linkage was found for baboon adiponectin protein in the present investigation, results from the genome-wide scan indicate that a QTL influencing mRNA levels maps to an area on baboon chromosome $4 \mathrm{p}$ between microsatellite marker loci D6S422 and D6S1718, which is orthologous to the human 6 p21 region. This same region has been linked to insulin resistance and type 2 diabetes traits in human studies (Norman et al., 1995; Luo et al., 2001; An et al., 2005). Recently, An et al. (2005) reported QTL in this region for parameters of glucose metabolism in response to exercise training in Whites and Blacks. A study by Norman et al. (1995) identified significant evidence for a QTL influencing variation in percentage of body fat in a sib-pair study in Pima Indians. To our knowledge, this is the first linkage analysis using adiponectin mRNA expression as a quantitative phenotype.

A positional candidate in this region, based on the human map, is the tumor necrosis factor- $\alpha$ (TNF $\alpha$, GI: 89161210), which is a well-characterized adipokine associated with obesity-induced insulin resistance, increased adipocyte volume and regulation of the expression of adiponectin (Bruun et al., 2003). There are four human and two rodent studies showing association between genetic variations in tumor necrosis factor- $\alpha$ and adiposity-related phenotypes (body mass index, percentage of body fat, waist circumference) (Hanson et al., 1998). One human study reported an association between the $-308 \mathrm{G} / \mathrm{A}$ single nucleotide polymorphism in the tumor necrosis factor- $\alpha$ gene and expression of adiponectin (Rankinen et al., 2006). Other positional candidates in this chromosomal region include the peroxisome proliferator-activated receptor- $\delta$ (PPAR- $\delta$, GI: 89886454) and glucagon-like peptide receptor 1 (GLP1R, GI: 402480).

In summary, the sequence and tissue-specific expression of baboon adiponectin showed a high degree of similarity to human. Our results confirmed a genetic contribution to the variation of adiponectin protein levels in blood and the presence of common genes influencing adiponectin levels, triglycerides and body mass, as observed in human studies. The present study provided novel findings suggesting the existence of genes controlling adiponectin expression and cell volume and other phenotypes related to obesity and insulin resistance. In addition, our investigation identified a new QTL linked to adiponectin mRNA expression. This QTL harbors some positional candidates that have previously been proposed using diabetes-related traits in human studies.

\section{Acknowledgements}

This work was supported by NIH Grants HL28972, RR3986 and MH59490.This investigation was conducted in a facility constructed with support from Research Facilities Improvement Program Grant no. C06 RR1355601 from the National Center for Research Resources, NIH.

\section{References}

Almasy L, Blangero J (1998). Multipoint quantitative-trait genetic analysis in general pedigrees. Am J Hum Genet 62: 1198-1211.

An P, Teran-Garcia M, Rice T, Rankinen T, Weisnagel SJ, Bergman RN et al. (2005). Genome-wide linkage scans for prediabetes phenotypes in response to 20 weeks of endurance exercise training in non-diabetic whites and blacks: the HERITAGE family study. Diabetologia 48: 1142-1149.

Banks WA, Altmann J, Sapolsky RM, Phillips-Conroy JE, Morley JE (2003). Serum leptin levels as a marker for a syndrome X-like condition in wild baboons. J Clin Endocrinol Metab 88: 1234-1240.

Blangero J, Williams JT, Almasy L (2000). Robust LOD scores for variance component-based linkage analysis. Genet Epidemiol 29: S8-S14.

Bruun J, Lihn AS, Verdich C, Pedersen SB, Toubo S, Astrup A et al. (2003). Regulation of adiponectin by adipose tissuederived cytokines: in vivo and in vitro investigations in humans. Am J Physiol Endocrinol Metab 285: E527-E533.

Butte NF, Comuzzie AG, Cai G, Cole SA, Mehta NR, Bacino CA (2005). Genetic and environmental factors influencing fasting serum adiponectin in Hispanic children. J Clin Endocrinol Metab 90: 4170-4176.

Cai G, Cole SA, Tejero ME, Proffitt JM, Freeland-Graves JH, Blangero J et al. (2004). Pleiotropic effects of genes for insulin resistance on adiposity in baboons. Obes Res 12: 1766-1772.

Chen J, Tan B, Karteris E, Zervous S, Digby J, Hillhouse EW et al. (2006). Secretion of adiponectin by human placenta: differential modulation of adiponectin and its receptors by cytokines. Diabetologia 49: 1292-1302.

Chuang LM, Chiu YF, Sheu WH, Hung YJ, Ho LT, Grove J et al. (2005). Biethnic comparisons of autosomal genomic scan for loci linked to plasma adiponectin in populations of Chinese and Japanese origin. J Clin Endocrinol Metab 89: 5772-5778.

Comuzzie AG, Cole SA, Martin L, Dee Carey K, Mahaney MC, Blangero J et al. (2003). The baboon as a nonhuman model for the study of the genetics of obesity. Obes Res 11: 75-80.

Comuzzie AG, Funahashi T, Sonnenberg G, Martin LJ, Jacob HJ, Black AE et al. (2001). The genetic basis of plasma variation in adiponectin, a global endophenotype for obesity and the metabolic syndrome. J Clin Endocrinol Metab 86: $4321-4325$.

Comuzzie AG, Tejero ME, Funahasi T, Martin LJ, Kissebah A, Takahashi $\mathrm{M}$ et al. (2007). The genes influencing adiponectin levels also influence risk factors for the metabolic syndrome and the development of type 2 diabetes. Am J Hum Biol 79: 191-200.

Cox LA, Mahaney MC, VandeBerg JL, Rogers J (2006). A second-generation genetic linkage map of the baboon (Papio hamadryas) genome. Genomics 88: 274-281.

Esposito K, Pontillo A, Di Palo C, Giugliano G, Masella M, Marfella R et al. (2003). Effect of weight loss and lifestyle changes on vascular inflammatory markers in obese women: a randomized trial. JAMA 289: 1799-1804.

Feingold E, Brown PO, Siegmund D (1993). Gaussian models for genetic linkage analysis using complete high-resolution maps of identity by descent. Am J Hum Genet 53: 234-251.

Fernández Real JM, López Bermejo A, Casamitjana R, Ricart W (2003). Novel interactions of adiponectin with the endocrine system and inflammatory parameters. J Clin Endocrinol Metab 88: 2714-2718.

Fruebis J, Tsao TS, Javorschi S, Ebbets-Reed D, Erickson MR, Yen FT et al. (2001). Proteolytic cleavage product of 30-kDa adipocyte complement-related protein increases fatty acid oxidation in muscle and causes weight loss in mice. Proc Natl Acad Sci USA 98: 2005-2010.

Garaulet M, Perez-Llamas F, Fuente T, Zamora S, Tebar FJ (2000). Anthropometric, computed tomography and fat cell data in an obese population: relationship with insulin, leptin, 
tumor necrosis factor-alpha, sex hormone-binding globulin and sex hormones. Eur J Endocrinol 143: 657-666.

Hanson RL, Ehm MG, Pettitt DJ, Prochazka M, Thompson DB, Timberlake D et al. (1998). An autosomal genomic scan for loci linked to type II diabetes mellitus and body-mass index in Pima Indians. Am J Hum Genet 63: 1130-1138.

Heilbronn L, Smith SR, Ravussin E (2004). Failure of fat cell proliferation, mitochondrial function and fat oxidation results in ectopic fat storage, insulin resistance and type II diabetes mellitus. Int J Obes 28: S12-S21.

Hotta K, Funahashi T, Bodkin NL, Ortmeyer HK, Arita Y, Hansen BC et al. (2001). Circulating concentrations of the adipocyte protein adiponectin are decreased in parallel with reduced insulin sensitivity during the progression to type 2 diabetes in rhesus monkeys. Diabetes 50: 1126-1133.

Kershaw E, Flier J (2004). Adipose tissue as an endocrine organ. I Clin Endocrinol Metab 89: 2548-2556.

Lewis DS, Bertrand HA, McMahan CA, McGill Jr HC, Carey KD, Masoro EJ (1986). Preweaning food intake influences the adiposity of young adult baboons. J Clin Invest 78: 899-905.

Lihn AS, Bruun JM, Gengsheng $\mathrm{H}$, Pedersen SB, Jensen PF Richelsen B (2004). Lower expression of adiponectin mRNA in visceral adipose tissue in lean and obese subjects. Mol Cell Endocrinol 219: 9-15.

Lindsay RS, Funahashi T, Krakoff J, Matsuzawa Y, Tanaka S, Kobes S et al. (2003). Genome-wide linkage analysis of serum adiponectin in the Pima Indian population. Diabetes 52: 2419-2425.

Luo TH, Zhao Y, Li G, Yuan WT, Zhao JJ, Chang JL et al. (2001). A genome-wide search for type II diabetes susceptibility genes in Chinese Hans. Diabetologia 44: 501-506.

Maeda K, Okubo K, Shimomura I, Funahashi T, Matsuzawa Y, Matsubara K (1996). cDNA cloning and expression of a novel adipose specific collagen-like factor, apM1 (AdiPose most abundant gene transcript 1). Biochem Biophys Res Commun 221: 286-289.

Matsuda M, Shimomura I, Sata M, Arita Y, Nishida M, Maeda N et al. (2002). Role of adiponectin in preventing vascular stenosis. The missing link of adipo-vascular axis. J Biol Chem 277: 37487-37491.

Nakamura Y, Shimada K, Fukuda D, Shimada Y, Ehara S, Hirose $\mathrm{M}$ et al. (2004). Implications of plasma concentrations of adiponectin in patients with coronary artery disease. Heart 90: $528-533$.

Norman RA, Bogardus C, Ravussin E (1995). Linkage between obesity and a marker near the tumor necrosis factor-alpha locus in Pima Indians. J Clin Invest 96: 158-162.

Pausova Z (2006). From big fat cells to high blood pressure: a pathway to obesity-associated hypertension. Curr Opin Nephrol Hypertens 15: 173-178.

Pollin TI, Tanner K, O'connell JR, Ott SH, Damcott CM, Shuldiner AR et al. (2005). Linkage of plasma adiponectin levels to 3q27 explained by association with variation in the APM1 gene. Diabetes 54: 268-274.

Rankinen $\mathrm{T}$, Zuberi A, Chagnon YC, Weisnagel SJ, Argyropoulos G, Walts B et al. (2006). The human obesity gene map: the 2005 update. Obes Res 13: 381-490.

Rotter Sopasakis V, Sandqvist M, Gustafson B, Hammarstedt A, Schmelz M, Yang X et al. (2004). High local concentrations and effects on differentiation implicate interleukin-6 as a paracrine regulator. Obes Res 12: 454-460.

Shimada K, Miyazaki T, Daida H (2004). Adiponectin and atherosclerotic disease. Clin Chem Acta 344: 1-12.

Silha J, Krsek M, Skrha J, Sucharda P, Nyomba B, Murphy L (2003). Plasma resistin, adiponectin and leptin levels in lean and obese subjects: correlations with insulin resistance. Eur J Endocrinol 149: 331-335.

Tejero ME, Cai G, Goring HHH, Diego V, Cole SA, Butte NA et al. (2007). Linkage analysis of circulating levels of adiponectin in Hispanic children. Int J Obes 31: 535-542.

Tejero ME, Freeland-Graves JH, Proffitt JM, Peebles KW, Cole SA, Comuzzie AG (2004). Adiponectin, but not resistin expression in monocytes is associated with insulin resistance in baboons. Obes Res 12: 871-877.

Weyer C, Folwy JE, Bogardus C, Tataranni PA, Pratley RT (2000). Enlarged subcutaneous abdominal adipocyte size, but not obesity itself, predicts type II diabetes independent of insulin resistance. Diabetologia 43: 1498-1506.

Weyer C, Funahashi T, Tanaka S, Tataranni PA (2001). Hypoadiponectinemia in obesity and type 2 diabetes: close association with insulin resistance and hyperinsulinemia. J Clin Endocrinol Metab 86: 1930-1935. 